\title{
Essential oil extraction from herbs and their use in the food industry
}

\author{
CSABA DEZSŐ ANDRÁS - BERNADETTE SALAMON - ÉVA GYÖRGY - \\ EMŐKE (DOBRI) MIHOK - ALEXANDRU SZÉP \\ Sapientia Hungarian University of Transylvania, Department of Food Science, \\ Csíkszereda, Romania \\ alszep@uni.sapientia.ro
}

\begin{abstract}
Summary
Essential oil extraction of wild caraway and thyme was performed using a classical (HD) and microwave hydro-distillation (MWHD) and a laboratory supercritical fluid extraction (SFE) with a carbon dioxide as solvent. Our experiments demonstrated that the extraction yield of the essential oil performed in same conditions was influenced by the location of growth area; the maximum extraction yield of $10 \mathrm{ml} 100 \mathrm{~g}^{-1}$ caraway was obtained from dried seeds collected from Csíkmadaras. This quantity far exceeded the yield of the Újtusnád samples. In the case of wild caraway (Carum carvi L.), the extraction method influenced the composition of the essential oil (carvone/limonene ratio), the highest limonene content being achieved by classical hydro-distillation. In the case of thyme, this effect was not detected, the thymol/carvacrol ratio was independent from the given extraction method. The obtained thyme essential oil possesses high antimicrobial activity demonstrated by agar diffusion test. The thyme extract provides a good protection against microorganisms collected on the surface of fresh vegetables following bacterial stains: Citrobacter portucalensis, Pseudomonas hunanensis, Pseudomonas baetica, Pseudomonas parafulva, Bacillus mojavensis and Enterobacter cloacae. Protective effect was also detected on the vegetable surface of by chitosan-based edible film coating during a 6-day-long storage period at a temperature of $4{ }^{\circ} \mathrm{C}$. The caraway essential oil used as soft cheese seasoning with a direct, dilution-free method, proved to be unsuitable because the uneven distribution and confer a strong, unpleasant taste to the product in comparison with the ground wild caraway seed-dressed cheese.
\end{abstract}

Keywords: essential oil, caraway, thyme, carvone, limonene, antimicrobial effect, edible coating, growth area

\section{Introduction}

The use of plant-based compound in human nutrition as nutraceuticals is becoming increasingly widespread (Gupta, 2016). Of the approximately 3000 known essential oils in 2004, 300 were used in industrial quantities (Burt, 2004). Their use in the food industry, in addition to the characteristic aroma, is mainly due to the antimicrobial effect of some of their components (Preedy, 2015; Shojaee-Aliabadi et al., 2018). The 
growing market led to an increase in the number of researches aimed at modernizing the extraction methods. At present, many laboratory and industrial processes are known for extracting essential oils, starting from classical to modern energy input (microwave, pulse, oral, ohmic) methods (Mandal et al., 2015). For the extraction of essential oil, classical water vapor distillation is used (both at the laboratory and in the small scale); in industrial-scale production, percolation, solid-fluid extraction and, last but not least, the supercritical fluid extraction method is extended (Roohinejad et al., 2018).

In the European Pharmacopoeia (Ph. Eur.) the vapor distillation (VD) is presented in both known methods: hydro-distillation-HD (vapor evolves from the herb suspension in the cooking bowl) and classic water steam distillation-SD (the steam generated in the steam generator flows through the plant cartridge). Direct heating can be achieved by boiling water under pressure, water vapor, electrical resistance (heating basket).

More modern versions of microwave heating (Kapás et al., 2011; Navarrete et al., 2011; Chemat et al., 2013) can be used for steam development, distillation or pretreatment. In pretreatment it is possible to use enzymatic digestion, where different fiber destruction (cellulase, hemicellulase, xylanase), pectin degradation (pectinase) or other enzymes (such as protease) are used (Bhat, 2000; Kashyap et al., 2001). Microwave assisted hydro-distillation (MHD) usually involves the use of freshly harvested parts of plants, whereby the required water vapor is provided by moisture. In case of solid-fluid extraction, it is necessary to form the appropriate dried particle size (grinding or crushing) as the internal diffusion is the rate determining step of the extraction process. Different energy inputs methods are used to increase the extraction yield, such as intense mixing-Turbo HD-(Manayer et al., 2015), ultrasound (Deng et al., 2014; Gavahian et al., 2015; Roselló-Soto et al., 2015; Koubaa et al., 2016), or pulsating electric field (Dobreva et al., 2013). A high pressure-high temperature fast extraction method has been developed, giving good results. The short-time high pressure steam treatment is followed by a sudden drop in pressure, and the formed vapors breaks the cell walls explosively, and subsequently they are separated from gas phase by condensation (Chemat et al., 2017).

For determination of essential oil yield, weighing or volume measurement is used. The water-essential oil mixture is a heteroazeotropic system, the condensate separates in two phase (water and essential oil) as the two compounds are very low mutual solubility. The most suitable laboratory apparatus for essential oil obtaining is the Clevenger-head, where the position of the backflow connection is adjusted the essential oil/water density ratio (Clevenger, 1928; Hornok, 1990). The following of the position change of the separation meniscus (in 
the graduated collecting capillary) in time is effective for measuring the kinetic of the hydro-distillation (Kapás et al., 2011). The extraction yield is influenced by a number of factors, as the growing zone, harvesting time, pre-treatment parameters and the extraction techniques (Bailer et al., 2001; Calin-Sanchez et al., 2013; Roohinejad et al., 2018).

The anticonvulsant effect of caraway tee used in folk medicine is acknowledged by modern medicine. Also it has been demonstrated that the essential oil inhibits the proliferation of Escherichia coli, Streptococcus faecalis, Staphylococcus aureus and other pathogenic microorganism living in the colon. The antimicrobial effect is attributed to D-limonene and carvone content (Zhang et al., 2014), as the antimicrobial activity of this components is confirmed experimentally (Shojaee-Aliabadi et al., 2018). In addition to its beneficial effect on digestion, it also improves liver function and has proven antioxidant potential (Samojlik et al., 2010).

The folk cuisine uses caraway seeds (in ground or intact form) as a spice, also is used as herb for the preservation and flavoring of edible fatty oils, as olive oil (for salad dressing), where the product it also enriched in aroma (Farag et al., 1989, 1990). Essential oil of wild caraway give a pleasant aroma and flavor to foods and provide also microbial protection, given by carvone and limonene content (Lopez et al., 2005; Čvek et al., 2010; György and György 2010; Jeong et al., 2014). Analyzing of antimicrobial effects it was demonstrated (Mohinger et al., 2013) that caraway essential oil has a good inhibitory effect on several microbial strains (Listeria monocytogenes, S. aureus, B. cereus, E. coli O157:H7 and Salmonella typhimurium) without decreasing the growth of lactic acid bacteria (L. delbrueckii ssp. bulgaricus and S. thermophilus). It is claimed that 0.3 to $0.5 \%$ of caraway essential oil caused a $1.3 \log$ to $4 \log$ decrease of E-coli O157:H7 in soft yoghurt cheese (Mohamed et al., 2013) in 7 and 14 days. The antimicrobial effect of other essential oils, including thyme, oregano, etc. has been largely studied, positive results being reported for many foods (Khorshidian et al., 2018). As our previous experiments shown, the obtaining method, the extraction time, the pretreatment and the plant vegetation stage and influenced the both the distillation kinetics as well as the major components ratio (András et al., 2014, 2015ab). Since the location of the growing field may have influence, we studied the effect of harvesting location on essential oil yield and composition.

\section{Material and method}

The wild caraway samples were collected from Csík (Ciuc) Depression (Csíkmadaras/Mădăraş, Hargitafürdő/Băile Harghita, Zsögöd/Jigodin and Újtusád/Tuşnadu Nou), thyme samples from Szelterszfürdő/Băile Selters (Harghita County) mountain pastures. The plant material was 
first classified (the green and ripe shoots was separated) then dried, sieved and finally elutriated in air current. The selected grains were stored in a dry place until analysis. The after-dried seeds (to equilibrium moisture) were grounded in Retsch Grindomix GM 200 laboratory mill.

The extraction was carried out by hydro-distillation method, using a laboratory vapor distillation apparatus (Figure 1), with $1.5 \mathrm{ml}(0.01 \mathrm{ml}$ divisions) volume Clevenger collector, a $125 \mathrm{~W}$ electrically heated roundbottom flask, corresponding to the Pharmacopoeia. Also, microwave hydro-distillation was performed (Kapás et al., 2011) in a modified microwave apparatus (Figure 2). The sample amount was $10 \mathrm{~g}$ of dried, grounded seeds, suspended in $200 \mathrm{ml}$ distilled water.

The supercritical fluid extraction (SFE) was performed with Supercritical Fluid Technology SFT 100 System (András et al., 2015a), where in a $10 \mathrm{ml}$ volumetric tube extractor operated at $40{ }^{\circ} \mathrm{C}$ temperature and above $10 \mathrm{MPa}$ pressure. The essential oil from the ground seeds was extracted with supercritical carbon dioxide. Sampling was performed by opening the isothermal valve heated to $42{ }^{\circ} \mathrm{C}$; the condensed essential oil was collected in a collector.

Figure 1. Schematic representation of the hydro-distillation equipment with Clevenger collector

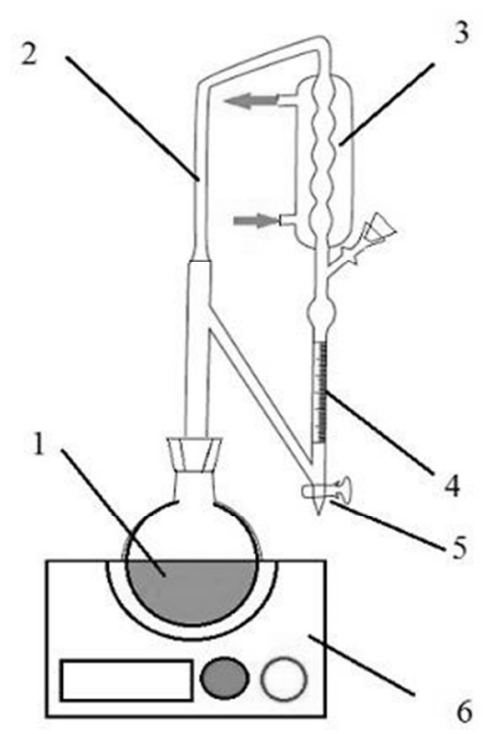

Note: 1. Round-bottom flask, 2. Steam tube, 3. Vapor condenser, 4. Scaled capillary for volume measure, 5. Stopcock, 6. Electric heater (125 W) 
Figure 2. Schematic representation of the microwave hydro-distillation equipment with Clevenger collector

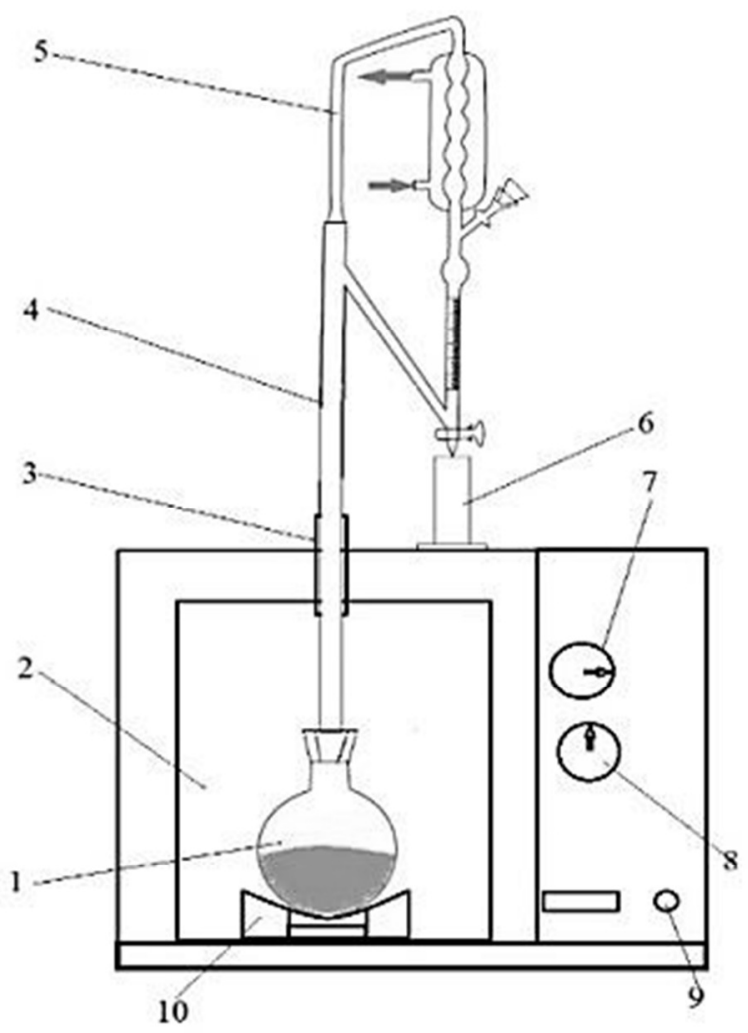

Note: 1. Round-bottom flask, 2. Heating circuit of a microwave furnace 3. Shielding tube, 4 . Vapour outlet tube, 5. Clevenger collector, 6. Sample collector, 7. Timer, 8. Power regulator, 9. On/off switch, 10. Teflon round bottom bracket.

Gas chromatography method was used to determine the quality and relative chromatographic percentages of essential oil components. Gas chromatography (GC-FID) conditions for each sample was the same: Varian CP 3380 apparatus, $100 \times 0.25 \mathrm{~mm}$ quartz-capillary column CPSil88 (FAME), flame ionization detector (FID) at $270{ }^{\circ} \mathrm{C}$ detector and injector temperature, carrier gas hydrogen $(235 \mathrm{kPa})$. The temperature program: heating to $50{ }^{\circ} \mathrm{C}$ for $1 \mathrm{~min}$, then heating with gradient of $5{ }^{\circ} \mathrm{C}$ $\mathrm{min}^{-1}$ to the final temperature $\left(210 \ldots 270{ }^{\circ} \mathrm{C}\right)$. Anhydrous sodium sulfate was used to remove the water residue from the samples. The injected sample $(\mathrm{V}=1 \mu \mathrm{L})$ with volatile oil $/ n$-hexane ratio equal to 1:15. Reference chromatogram (Kubeczka and Formácek, 2002) was used to evaluate the results. 
At the laboratory level, two practical utilization experiments of the essential oil were carried out. In the first, we investigated the antimicrobial effect of the thyme extract and some of the commercially available essential oils (cinnamon, oregano, juniper, mint and lemongrass); while in the second experiment we measured the flavoring effect of the wild-caraway essential oil in cheese. The effect thyme essential oil on Citrobacter portucalensis, Pseudomonas hunanensis, Pseudomonas baetica, Pseudomonas parafulva, Bacillus mojavensis and Enterobacter cloacae microbes, isolated from fresh vegetable, was estimated by measuring the inhibition zone diameter. After the solidification of the sterile nutrient media filled in the Petri dish, the test bacteria were plated by plating and a $10 \mathrm{~mm}$ diameter hole was prepared in the center of the cup to which $0.1 \mathrm{ml}$ of essential oil was pipetted.

After the incubation time has elapsed, the diameter of the inhibition zone was measured. Based on the results, the most efficient antimicrobial oil was chosen. Essential oil additivated chitosan-based edible coating was prepared and applied on tomato surface, to perform storage experiments $\left(6\right.$ days at $4{ }^{\circ} \mathrm{C}$ ), than deterioration inhibition was evaluated (compared with the control sample).

In the second experiment we flavored soft cheese with ground nonground wild caraway seeds and their essential oil, produced in the laboratory. For the qualification of the final product a sensory test with questionnaire was performed. Flavoring was done after the curd breaking by added the seeds or extract. In each experiment we followed the same cheese-making procedure $\left(65^{\circ} \mathrm{C}\right.$ pasteurization temperature, 15 min holding time, cooling to $32{ }^{\circ} \mathrm{C}$, inoculation with propionic acidproducing bacteria $(0.8 \mathrm{~g}$ per $2.3 \mathrm{l}$ ) and enzyme (0.09 g per $2.3 \mathrm{l}$ ), coagulation process at $32{ }^{\circ} \mathrm{C}$ temperature and 3 hour duration, curd cutting uniformly, partial elimination the whey, flavoring by mixing (12.5 g of wild caraway per $2.31,15$ g grounded wild caraway per 2.31 and 1 $\mathrm{ml}$ of essential oil per $2.3 \mathrm{l}$ ), whey elimination at $4{ }^{\circ} \mathrm{C}$ temperature, chilled maturation in cylinder form with daily flip of product, sensory qualification).

The mixture for chitosan-based antimicrobial edible coating film was prepared as follows: $1 \mathrm{~g}$ of acetic acid was diluted with $100 \mathrm{ml}$ distilled water, and then $2 \mathrm{~g}$ of chitosan was added. The mixture was homogenized for 4 hours with magnetic stirrer, isothermal at $25^{\circ} \mathrm{C}$. Then $2 \mathrm{~g}$ of glycerol, Tween 20 solution and $0.3 \mathrm{~g}$ of essential oil were mixed and agitated to the former. After 10 minutes stirring was homogenized and degassed for 30 minutes in an ultrasonic bath for obtaining the coating mixture). The formed viscous gel was used to coating the vegetable, the film on vegetable surface was formed by immersion. The edible film-coated vegetable was stored at $4{ }^{\circ} \mathrm{C}$ for 6 days before analysis. 


\section{Results and discussion}

Essential oil yield variation of samples from different growth field

The data analysis of the experimental results shown, that the obtained quantity of essential oil was influenced by the growth location in both case (for green and ripe wild caraway). As shown in Figure 3, parallel measurements of two samples from the same location are situated almost on the same curve. This indicate the homogeneity of the samples.

Figure 3. Kinetic curves of hydro-distillation yield of green seeds collected from different growing location

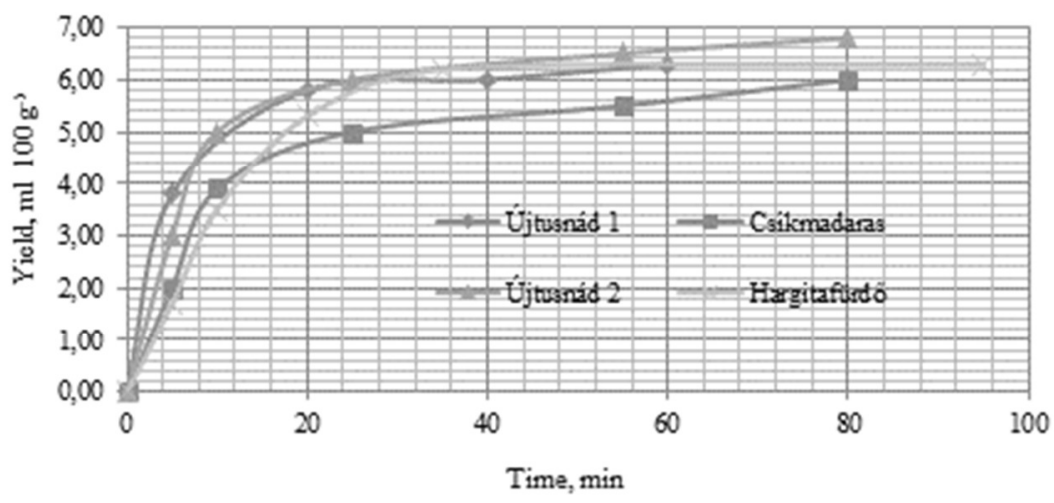

Furthermore, it can be observed that for samples from different growth locations the yields show quite large variations. The highest essential oils yield from green caraway is provided from Újtusnád samples. The essential oil yields for ripe wild caraway are shown in Figure 4. The ripe samples from Csíkmadaras the highest essential oil content, much more than the samples of Zsögöd and Hargitafürdő.

The linearization method was used to determine the parameters of hydrodistillation kinetics (Milojević et al., 2008; Kapás et al., 2011). Figure 5 shows that for green caraway the model describes with a medium accuracy change of extracted quantity in time $\left(R^{2}=0.87-0.94\right)$, but for ripe (mature) caraway (where the two phases separated in Clevenger-head) more accurate results were obtained $\left(\mathrm{R}^{2}=0.93-0.99\right)$.

Comparing the values of maximum yields (Figure 6), we find that these are different for different growth location. The highest yield was observed for mature caraway from Csíkmadaras. Analyzing the composition of the essential oil it can be observed that, although the number of components varies, the two main constituents - limonene and carvone - represent more than $85 \%$ of the mixture, for both, green and mature seeds of wild caraway evenly. 
Figure 4. Kinetic curves of hydro-distillation yield of mature wild caraway collected from different growing location

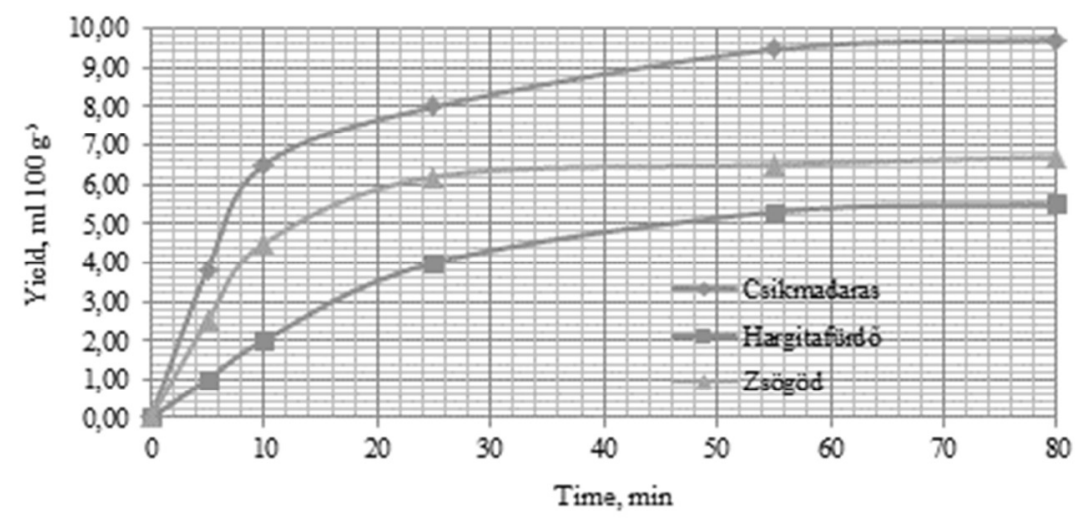

Figure 5. The linearized kinetics for model parameters determination
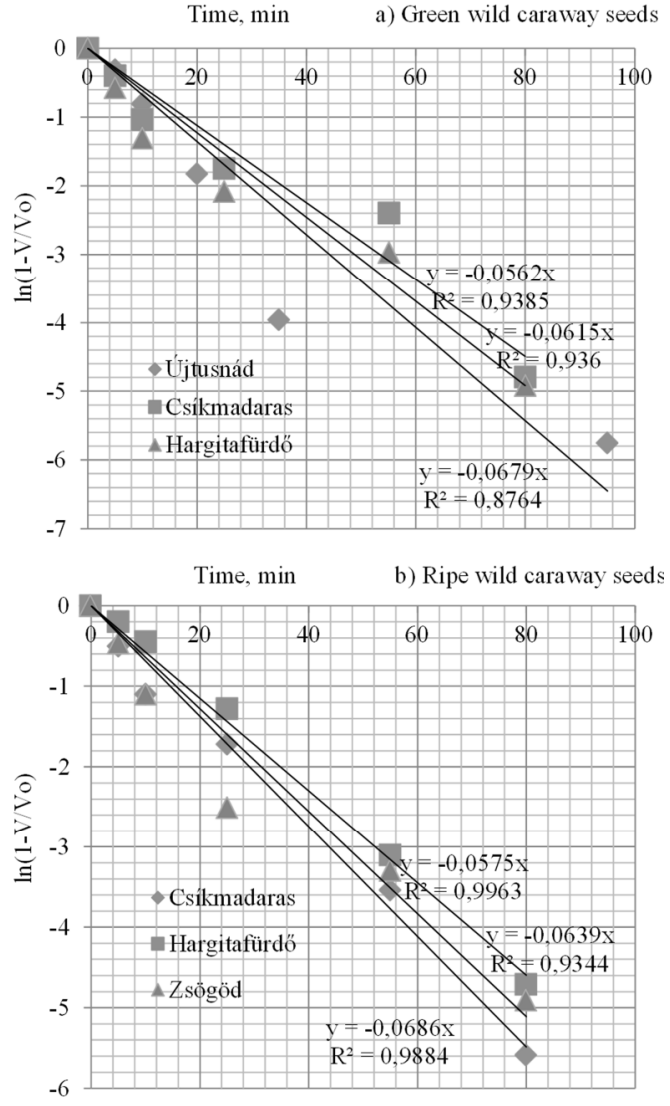
Figure 6. Variation of the maximum essential oil yield in function of harvesting location and year

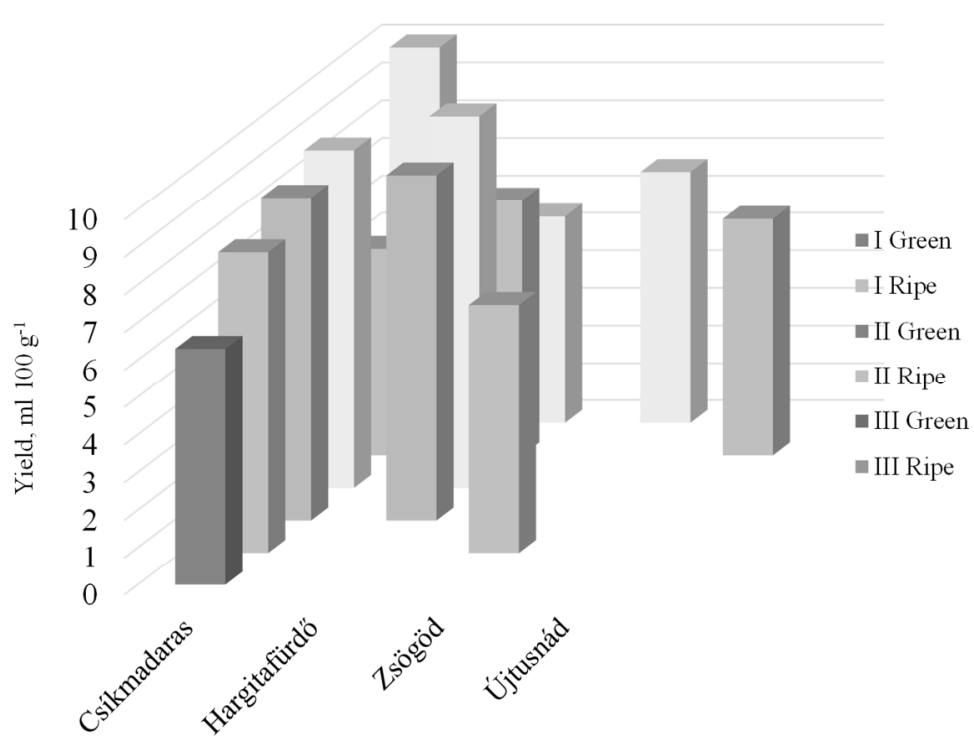

Analyzing the relative amount (weight percentage) of the two main components (Figure 7) shown that the ratio of D-limonene in the Csíkmadaras sample extract is higher than in other samples (for green and mature samples both). It can also be observed, that in case of hydrodistillation obtained essential oils, the proportion of limonene is higher than for supercritical extract. It has been demonstrated that supercritical extraction is more selective than other extraction methods (András et al., 2002), but in this case (batch experiments) the observed increase of carvone proportion may attributable to the most volatile component loss (limonene) in sample collection step. No major difference in the essential oil quality thyme of wild obtained by HD and SFE can be observed. The chromatograms of the thyme essential oils obtained by different methods are represented on Figure 8. Regardless of the obtaining method, the retention time of the main components are the same for all three chromatograms. The similar relative amount of the main compounds (thyme and carvone) shows that the extraction method did not affect the composition of the obtained product. 
Figure 7. The relative amount (percentage by weight) of the two main components for hydro-distillation and supercritical fluid extraction of essential oils of wild caraway collected from different growth area

a) green wild caraway seeds; b) ripe wild caraway seeds

a

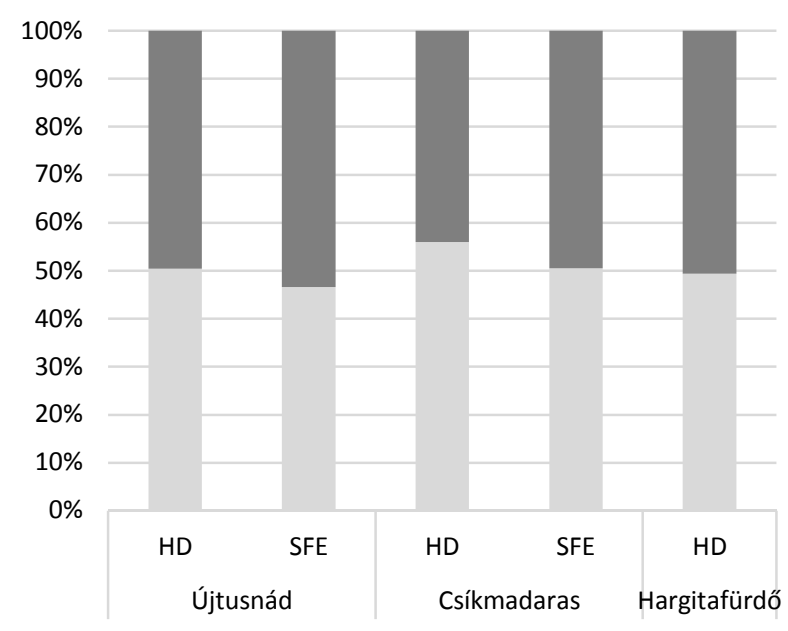

Limonene $\quad$ Carvone

b

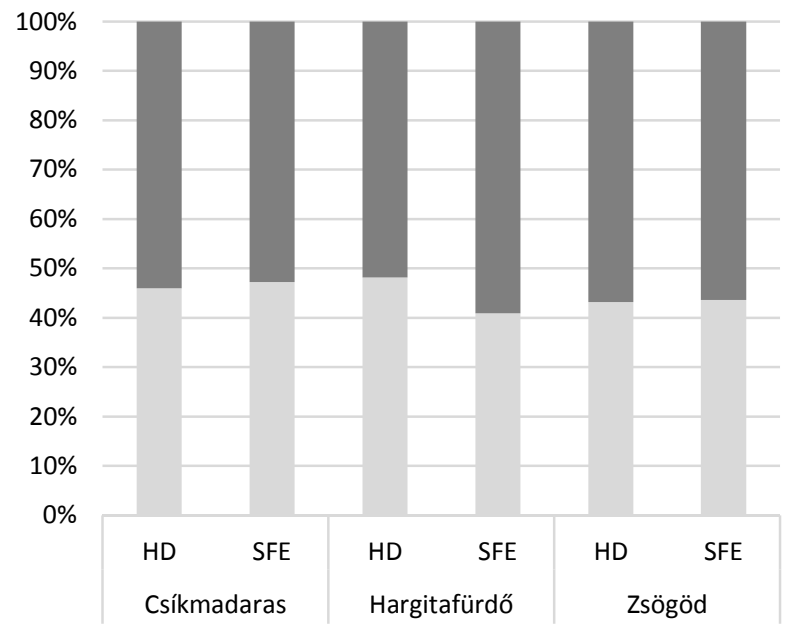

Limonene $\quad$ Carvone 
Figure 8. The chromatograms of the thyme extracts (SFE 9/1 supercritical extraction, HD hydro-distillation, MWHD-microwave assisted hydro-distillation)
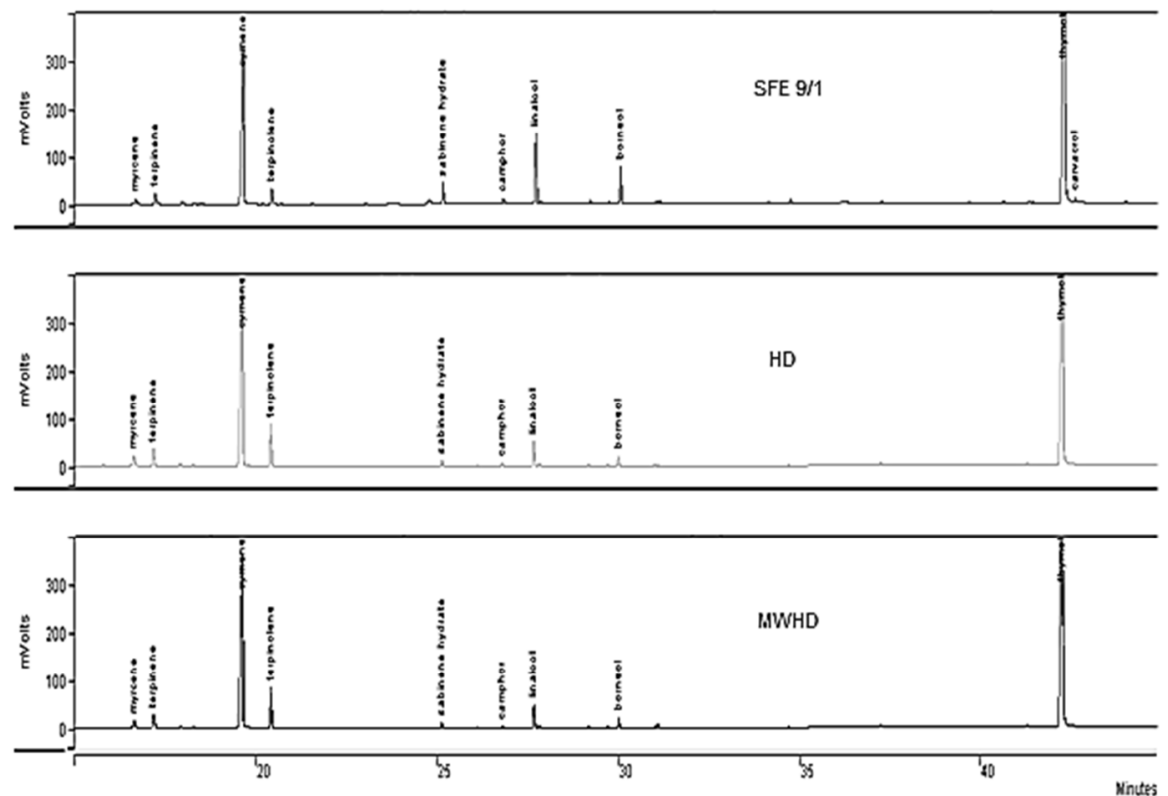

The antimicrobial effect of the thyme extract

The result presented in Table 1 refer to the magnitude of inhibition zones (in millimeters) generated by the antimicrobial effect of the essential oils.

Table 1. Antimicrobial effect of the analyzed essential oils

\begin{tabular}{|c|c|c|c|c|c|c|}
\hline $\begin{array}{c}\text { Tested } \\
\text { microorganism }\end{array}$ & $\begin{array}{c}\text { Cinnamon } \\
\text { oil }\end{array}$ & $\begin{array}{c}\text { Oregano } \\
\text { oil }\end{array}$ & $\begin{array}{c}\text { Thyme } \\
\text { oil }\end{array}$ & $\begin{array}{l}\text { Lemon- } \\
\text { grass oil }\end{array}$ & $\begin{array}{c}\text { Mint } \\
\text { oil }\end{array}$ & $\begin{array}{c}\text { Juniper } \\
\text { oil }\end{array}$ \\
\hline $\begin{array}{l}\text { Enterobacter } \\
\text { cloacae }\end{array}$ & $7.2 \pm 0.75$ & $13.8 \pm 1.94$ & $8.2 \pm 0.4$ & $\begin{array}{c}\text { No } \\
\text { inhibition }\end{array}$ & $\begin{array}{c}\text { No } \\
\text { inhibition }\end{array}$ & $\begin{array}{c}\text { No } \\
\text { inhibition }\end{array}$ \\
\hline $\begin{array}{l}\text { Pseudomonas } \\
\text { parafulva }\end{array}$ & $7.6 \pm 0.8$ & $9.0 \pm 1.41$ & $3.4 \pm 1.02$ & $\begin{array}{l}\text { No } \\
\text { inhibition }\end{array}$ & $\begin{array}{l}\text { No } \\
\text { inhibition }\end{array}$ & $\begin{array}{l}\text { No } \\
\text { inhibition }\end{array}$ \\
\hline $\begin{array}{l}\text { Pseudomonas } \\
\text { baetica }\end{array}$ & $7.4 \pm 0.49$ & $27.6 \pm 3.2$ & $27 \pm 3.95$ & $12 \pm 1.1$ & $8.0 \pm 1.1$ & $18 \pm 3.03$ \\
\hline $\begin{array}{l}\text { Bacillus } \\
\text { mojavensis }\end{array}$ & $5.8 \pm 0.75$ & $16.8 \pm 0.75$ & $35.4 \pm 1.36$ & $7.0 \pm 1.26$ & $1.8 \pm 0.75$ & $16 \pm 2.61$ \\
\hline $\begin{array}{l}\text { Pseudomonas } \\
\text { hunanensis }\end{array}$ & $2.4 \pm 0.49$ & $5.8 \pm 1.94$ & $5.6 \pm 0.49$ & $5.8 \pm 0.75$ & $\begin{array}{c}\text { No } \\
\text { inhibition }\end{array}$ & $\begin{array}{l}\text { No } \\
\text { inhibition }\end{array}$ \\
\hline $\begin{array}{l}\text { Citrobacter } \\
\text { portucalensis }\end{array}$ & $8.8 \pm 0.75$ & $30.6 \pm 0.8$ & $9.8 \pm 1.47$ & $3.0 \pm 1.26$ & $4.2 \pm 0.75$ & $\begin{array}{c}\text { No } \\
\text { inhibition }\end{array}$ \\
\hline
\end{tabular}

This results show that the strongest inhibitor was the thyme essential oil, which proved to be the most effective for all studied bacteria, only the 
oregano oil compete with it. This result is in a good agreement with recent literature data (Memar et al., 2017). In contrast, mint, lemongrass, and especially juniper essential oil were ineffective against several bacteria.

The effect of the thyme extract on surface microbe development was tested by film coating. After storage, the difference between the filmcoated (left) and uncoated cocktail tomato (right) was well-displayed (Table 2). Untreated cocktail tomato started to deteriorate, on the surface patches of brown and softs spots appeared, changes in consistency, and molding began. In contrast, the coated cocktail tomato remained in good condition, in terms of its appearance and its texture.

Table 2. The antimicrobial effectiveness of the thyme extract-containing coating film on the cocktail tomato after short time storage

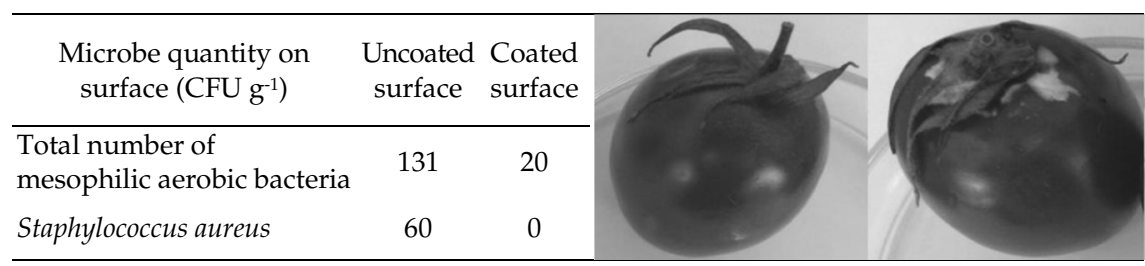

Characterization of the wild caraway-flavored soft cheese

Our laboratory experiments have demonstrated that in the case of soft cheese, only the seeds (in ground and ungrounded form) could be use after the curd thickening, otherwise it is very difficult to ensure uniform distribution in the mixture. The addition of essential oil of wild caraway in curd was difficult, due by the important changes in cheese texture caused by even small quantities of dispersed essential oil. The uneven distribution causes great displeasure in the sensorial analysis, each of the 10 persons highlighted the strong aroma of some cheese pieces, which could be prevented only by a more efficient dispersion method.

\section{Conclusions}

Our experiments demonstrate that the growing field has great influence on the essential oils yield but less on the of the two main components (carvone and limonene) ratio. The highest yield was obtained from the Csíkmadaras harvested samples, while the highest carvone/limonene ratio was provided by the supercritical extraction. For wild caraway samples the essential oil extraction composition was influenced by the extraction method, but for extraction of thyme samples, for essential oil with lower volatility this behavior was not observed. In case of thyme 
essential oil the ratio of relative amount (mass \%) of the main components (thymol and carvacrol) remained the same for all three obtaining methods. The laboratory test have proven that the thyme essential oil possess inhibition effect on the microorganisms growth collected from the surface of fresh vegetables. The inhibitory effect of thyme was comparable with oregano. The edible chitosan coating contained thyme extract on tomato surface possess positive effect in storage for six days, protecting its consistency from bacterial deterioration processes. Industrial applicability requires the acquisition of more laboratory information regarding the molds growth and the synergistic effects of essential oils. Regarding the use of wild caraway essential oil as a flavoring agent of cheese it can be concluded, that without uniform distribution of even a small quantity of EO-s, the product did not win the appreciation of the sensorial evaluators.

\section{References}

*** (2014): Essential oils in herbal drugs In European Pharmacopoeia (Ph. Eur.), Eight Edition. European Directorate for the Quality of Medicine \& Health Care (EDQM). Strasbourg. 273-274.

András Cs. D.-Salamon V. R.-Volf I.-Barabás I.-Szép Al. (2015b): A kinyerési módszer befolyása a vadkömény-illóolaj kihozatalára és fő komponenseire. Múszaki Szemle. 65: 3-9.

András Cs. D.-Simándi B.-Farsang R.-Hamucska K.-Héthelyi B. É.-Domokos J.-Deák A. (2002): Fúszerkömény (Carum carvi L.) extrakciója szuperkritikus széndioxiddal. J. Oil Soap Cosmet. 51: 64-68.

András Cs. D.-Szép Al.-Salamon R.V.-Barabás I. (2014): Az előkezelési mód hatása a vadkömény illóolaj kinyerésére és minőségére. Múszaki Szemle. 63: 3-10.

András, C. D.-Salamon, R. V.-Barabás, I.-Volf, I.-Szép, A. (2015a): Influence of extraction methods on caraway (Carum carvi L.) essential oil yield and carvone/limonene ratio. Environ. Eng. Manag. J. 14. 2: 341-350.

Bailer, J.-Aichinger, T.-Hackl, G.-de Hueber, K.-Dachler, M. (2001): Essential oil content and composition in commercially available dill cultivars in comparison to caraway. Ind. Crops Prod. 14. 3: 229-239.

Bhat, M. K. (2000): Cellulases and related enzymes in biotechnology. Biotechnol. Adv. 18. 5: 355-383.

Burt, S. (2004): Essential oils: Their antimicrobial properties and potential applications in foods. A review. International Journal of Food Microbilogy. 94. 3: 223-253.

Calin-Sanchez, A.-Figiel, A.-Lech, K.-Szumny, A.-Carbonell-Barrachina, A. A. (2013): Effect of drying methods on the composition of thyme (Thymus vulgaris L.) essential oil. Drying Technol. 31. 2: 224-235. 
Chemat, F.-Abert-Vian, M.-Fernandez, X. (2013): Microwave-assisted extraction of essential oils and aromas. [In: Chemat, F.-Cravotto, G. (eds.) Microwave Extraction for Bioactive Compounds. Theory and Practice.] Springer Science+Business Media. New York.

Chemat, F.-Rombaut, N.-Meullemiestre, A.- Turk, M.-Perino, S.- Fabiano-Tixier, A. S.-Abert-Vian, M. (2017): Review of green food processing techniques. Preservation, transformation, extraction. Innov. Food Sci. Emerg. Technol. 41: 357-377.

Clevenger, J. E. (1928): Apparatus for the determination of volatile oil. J. Am. Pharm. Assoc. 17: 345-349.

Čvek, D.-Markov, K.-Frece, J.-Dragičević, T. L.-Majica, M.-Delaš, F. (2010): Growth inhibition of Aspergillus ochraceus ZMPBF 318 and Penicillium expansum ZMPBF 565 by four essential oils. Arh. Hig. Rada Toksikol. 61. 2: 191-196.

Deng, Q.-Zinoviadou, K. G.-Galanakis, C. M.-Orlien, V.-Grimi, N.-Vorobiev, E.Lebovka, N.-Barba, E. J. (2014): The effects of conventional and nonconventional processing on glucosinolates and its derived forms, isothiocyanates: Extraction, degradation, and applications. Food Eng. Rev. 7. 3: 357-381.

Dobreva, A.-Tintchev, F.-Dzhurmanski, A.-Toepfl, S. (2013): Effect of pulsed electric fields on distillation of essential oil crops. C. R. Acad. Bulg. Sci. 66. 9: 12551260.

Farag, R. S.-Ali, M. N.-Taha, S. H. (1990): Use of some essential oils as natural preservatives for butter. J. AOAC. 67. 3: 188-191.

Farag, R. S.-Badei, A. Z. M. A.-Hewedi, F. M.-El-Baroty, G. S. A. (1989): Antioxidant activity of some spice essential oils on linoleic acid oxidation in aqueous media. J. AOAC. 66. 6: 792-798.

Gavahian, M.-Farahnaky, A.-Farhoosh, R.-Javidnia, K.-Shahidi, F. (2015): Extraction of essential oils from Mentha piperita using advanced techniques: Microwave versus ohmic assisted hydrodistillation. Food Bioprod. Process. 94: 50-58.

Gupta, R. C. (ed.) (2016): Nutraceuticals: Efficacy, Safety and Toxicity. Elsevier Academic Press. Amsterdam.

György, É.-György, E. M. (2010): Study of the antimicrobial activity and synergistic effect of some plant extracts and essential oils. Rev. Romana Med. Lab. 18. 1: 49-56.

Hornok L. (1990): Gyógynövények termesztése és feldolgozása. Mezőgazda Kiadó. Budapest.

Jeong, E. J.-Lee, N. K.-Oh, J.-Jang, S. E.-Lee, J. S.-Bae, I. H.-Jeong, Y. S. (2014): Inhibitory effect of cinnamon essential oils on selected cheese-contaminating fungi (Penicillium spp.) during the cheese-ripening process. Food Sci. Biotechnol. 23. 4: 1193-1198.

Kapás, Á.-András, C. D.-Dobre, T. G.-Vass, E.-Székely, G.-Stroescu, M.-Lányi, S.Ábrahám, B. (2011): The kinetic of essential oil separation from fennel by microwave assisted hydro-distillation (MWHD), UPB Sci. Bull. B. 73. 4: 113120.

Kashyap, D. R.-Vohra, P. K.-Chopra, S.-Tewari, R. (2001): Applications of pectinases in the commercial sector. A review. Bioresour. Technol. 77. 3: 215-227. 
Khorshidian, N.-Yousefi, M.-Khanniri, E.-Mortazavian, A. M. (2018): Potential application of essential oils as antimicrobial preservatives in cheese. Innov. Food Sci. Emerg. Technol. 45: 62-72.

Koubaa, M.-Mhemdi, H.-Barba, F. J.-Roohinejad, S.-Greiner, R.-Vorobiev, E. (2016): Oilseed treatment by ultrasounds and microwaves to improve oil yield and quality: An overview. Food Res. Int. 85: 59-66.

Kubeczka, K. H.-Formácek, V. (2002): Essential Oil Analysis by Capillary Gas Chromatography and Carbon-13 NMR Spectroscopy. John Wiley \& Sons. Chichester. 37-40.

López, P.-Sánchez, C.-Batlle, R.-Nerín, C. (2005): Solid- and vapor-phase antimicrobial activities of six essential oils: Susceptibility of selected foodborne bacterial and fungal strains. J. Agric. Food Chem. 53. 17: 6939-6946.

Manayer, D.-Fabiano-Tixier, A. S.-Petitcolas, E.-Ruiz, K.-Hamieh, T.-Chemat, F. (2015): Simultaneous extraction of essential oils and flavonoids from onions using turbo-extraction-distillation. Food Anal. Methods. 8: 586-589.

Mandal, S. C.-Mandal, V.-Das, A. K. (2015): Essentials of Botanical Extraction: Principles and Applications. Academic Press. Amsterdam.

Memar, M. Y.-Raei, P.-Alizadeh, N.-Aghdam, M. A.-Kafil, H. S. (2017): Carvacrol and thymol: Strong antimicrobial agents against resistant isolates. Rev. Med. Microbiol. 28. 2: 63-68.

Milojević, S. Ž.-Stojanović, T. D.-Palić, R.-Lazić, M. L.-Veljković, V. B. (2008): Kinetics of distillation of essential oil from comminuted ripe juniper (Juniperus communis L.) berries. Biochem. Eng. J. 39. 3: 547-553.

Mohamed, S. H. S.-Zaky, W. M.-Kassem, J. M.-Abbas, H. M.-Salem, M. M. E-Said-Al Ahl, H. A. H. (2013): Impact of antimicrobial properties of some essential oils on cheese yoghurt quality. World Appl. Sci. J. 27. 4: 497-507.

Navarrete, A.-Wallraf, S.-Mato, R. B.-Cocero, M. J. (2011): Improvement of essential oil steam distillation by microwave pretreatment. Ind. Eng. Chem. Res. 50. 8: 4667-4671.

Preedy, V. R. (ed.) (2015): Essential Oils in Food Preservation, Flavor and Safety. Elsevier Academic Press, Amsterdam.

Roohinejad, S.-Koubaa, M.-Barba, F. J.-Leong, S. J.-Khelfa, A.-Greiner, R.-Chemat, F. (2018): Extraction methods of essential oils from herbs and spices. [In: Hashemi, B. S. M. et al. (eds.) Essential Oils in Food Processing. Chemistry, Safety and Applications.] Wiley Blackwell. Hoboken.

Roselló-Soto, E.-Galanakis, C. M.-Brncic, M.-Orlien, V.-Trujillo, F. J.-Mawson, R.Knoerzer, K.-Tiwari, B. K.-Barba, F. J. (2015): Clean recovery of antioxidant compounds from plant foods, by-products and algae assisted by ultrasounds processing. Modelling approaches to optimize processing conditions. Trends Food Sci. Tech. 42. 2: 134-149.

Samojlik,,I-Lakic, N.-Mimica-Dukic, N.-Akovic-Svajcer, K.-Bozin, B. (2010): Antioxidant and hepatoprotective potential of essential oils of coriander (Coriandrum sativum L.) and caraway (Carum carvi L.) (Apiaceae). J. Agric. Food Chem. 58. 15: 8848-8853.

Shojaee-Aliabadi, S.-Hosseini, S. M.-Mirmoghtadaie, L. (2018): Antimicrobial activity of essential oil. [In: Hashemi, B. S. M. et al. (eds.) Essential Oils in Food Processing. Chemistry, Safety and Applications.] Wiley Blackwell. Hoboken. 
Zhang, Z.-Vriesekoop, E.-Yuan, Q.-Liang, H. (2014): Effects on nisin on the antimicrobial activity of D-limonene and its nanoemulsion. Food Chem. 150: 307-312. 